\title{
The ensiling capability of a mixture of sodium benzoate, potassium sorbate, and sodium nitrite
}

\author{
M. Knicky and R. Spörndly ${ }^{1}$ \\ Department of Animal Nutrition and Management, Swedish University of Agricultural Sciences, Kungsängen Research Centre, 75323 Uppsala, \\ Sweden
}

\begin{abstract}
The objective of this study was to evaluate the effects of an additive comprising sodium benzoate, potassium sorbate, and sodium nitrite on the quality of silages fermented from various forage crops. Thirteen crops in 3 groups (differing in dry matter concentration and degree of ensilability) were treated with the additive mixture and compared with untreated control silages. The main focus was on yeast and Clostridia spp. activity in the silages, although other silage quality criteria also were measured. Treated silages from difficult-to-ensile crops at low dry matter were found to have significantly lower silage $\mathrm{pH}$, fewer clostridial spores, and reduced concentrations of ammonia $\mathrm{N}$, butyric acid, and ethanol. In addition, dry matter losses were reduced in treated silages compared with those receiving no additive. Similar results were observed in silages from easy or intermediate ensilable crops when the dry matter concentration was $<300 \mathrm{~g} / \mathrm{kg}$. When the dry matter concentration was $>350 \mathrm{~g} / \mathrm{kg}$, the treated silages contained less ammonia $\mathrm{N}$, ethanol, and yeast for 3 out of 4 forages. All treated silages from all crops were aerobically stable during the examination time. The application of the tested additive mixture reduced the growth of undesirable microflora and thereby reduced silage losses and prolonged the aerobic stability of the silages.
\end{abstract}

Key words: aerobic stability, clostridia, losses, silage fermentation

\section{INTRODUCTION}

Clostridia growth and poor aerobic stability are frequent problems when making and feeding silages. Clostridia are microorganisms that produce butyric acid and are responsible for the undesirable degradation of forage nutrients during fermentation in silages with low DM content. Additionally, clostridia spores reduce the quality of milk products, as with "blooming

Received April 22, 2010.

Accepted October 9, 2010.

${ }^{1}$ Corresponding author: rolf.sporndly@huv.slu.se cheese" (Pahlow et al., 2003). Poor aerobic stability in silages with higher DM content is associated with the growth of undesirable yeasts and molds and ultimately a reduction in crop nutrients (Woolford, 1978). These problems might be avoided by using selective additives, which promote good fermentation, improve aerobic stability, and reduce hygienic risks.

The antimicrobial properties of sodium benzoate, potassium sorbate, and sodium nitrite are well known and, as such, they are used as additives in the conservation of a variety of feeds and foods. In forage conservation, Woolford (1975) describes potassium sorbate as being effective in inhibiting spore-forming bacteria, yeasts, and molds in a pH range of 3 to 6 . Sodium benzoate exhibits similar antimicrobial properties, although these are reduced at higher $\mathrm{pH}$ values (Woolford, 1975). Sodium nitrite inhibits the growth of spore-forming bacteria, particularly at low $\mathrm{pH}$ levels (Woolford, 1975). Its potency is derived from the breakdown of nitrate in fresh forage to nitrite and nitric oxide, which both inhibit the growth of undesirable bacteria in silage (Spoelstra, 1983). The beneficial effect for silage quality of adding sodium benzoate and potassium sorbate has been reported by Kleinschmit et al. (2005). The potency of sodium nitrite in silages has been tested in combination with hexamine (Gross and Beck, 1972; Reuter and Weissbach, 1991; Kwella et al., 1993) and in mixtures with sodium benzoate and sodium propionate (Lättemäe and Lingvall, 1996; Lingvall and Lättemäe, 1999; Knicky and Lingvall, 2004). Despite the potency of hexamine-nitrite mixtures, concerns exist about their safety with regard to human and animal health. In acidic conditions, hexamine degrades to form ammonia and formaldehyde, which is, in many countries, a prohibited preservative. An environmental concern exists in regard to the quantity of used nitrite in an additive mixture. However, Knicky and Spörndly (2009) were the first to demonstrate the promising results from combining a reduced sodium nitrite with sodium benzoate and potassium sorbate to aid silage fermentation.

Most studies published with additives are conducted using only one crop and assuming that the results are 
applicable to different crops. That approach gives limited information to how effective the product will be in practical use. The objective of the present study however, is to evaluate the effectiveness of the product on many crops and therefore gives a general answer to the potential of the product in the agricultural business. Kwella et al. (1993) recommends testing the efficiency of silage additives under difficult ensiling conditions. Such conditions can represent crops with a fermentation coefficient $(\mathbf{F C})<35$ because they are difficult to ensile (Weissbach et al., 1974; Weissbach, 1996). At the same time, even well-fermented silages, often made from crops with FC $>45$ (Weissbach, 1996), are prone to aerobic deterioration.

Based on the result of Knicky and Spörndly (2009), a new silage additive has been launched commercially that is thought to be effective in both low- and highDM silages with high and low FC. The objective of this study was to examine the efficacy of this silage additive mixture, comprising sodium benzoate, potassium sorbate, and sodium nitrite, to prevent the growth of undesirable microflora in silages made from a wide range of different crops of various DM concentrations.

\section{MATERIALS AND METHODS}

Thirteen crops were harvested between June and October 2007 in or near Uppsala, Sweden $\left(59^{\circ} 50^{\prime} 32^{\prime \prime} \mathrm{N}\right.$, $\left.17^{\circ} 40^{\prime} 23^{\prime \prime} \mathrm{E}\right)$. The harvest conditions and botanical composition of the 13 crops are presented in Table 1. The crops were selected from local farms and cultivated according to normal agricultural practice in Sweden. For the leys, approximately 90 and $60 \mathrm{~kg}$ of nitrogen as mineral fertilizer was applied to the first and second cuts, respectively, and as farmyard manure once a year in the autumn. For whole-crop barley and maize, approximately $90 \mathrm{~kg}$ of nitrogen and $30 \mathrm{~kg}$ of phosphorus mineral fertilizer were applied at sowing, and farm yard manure was applied the autumn before. Except for crop 13, which was harvested using a Claas Jaguar (Claas KGaA, Harsewinkel, Germany) precision harvester, all forages were harvested manually using a scythe and chopped in a stationary cutter head to an approximately 5-cm particle length. Crops 10, 11, and 12 were wilted for 4 to $8 \mathrm{~h}$ before chopping. After chopping, the forages were mixed and divided into 2 fractions of $3 \mathrm{~kg}$ of fresh matter (FM) each. One forage fraction was treated with the silage additive, a water solution containing $200 \mathrm{~g}$ of sodium benzoate $/ \mathrm{kg}$ ( 1.53 $M), 100 \mathrm{~g}$ of potassium sorbate $/ \mathrm{kg}(0.73 \mathrm{M})$, and $50 \mathrm{~g}$ of sodium nitrite $/ \mathrm{kg}(0.8 \mathrm{M})$. The treatment rate was $5 \mathrm{~mL}$ of mixture per kilogram of FM for crops containing $<350 \mathrm{~g} / \mathrm{kg}$ of $\mathrm{FM}$, or $3 \mathrm{~mL}$ for crops containing $>350 \mathrm{~g} / \mathrm{kg}$ of FM, following the recommendation of the producer. The silage additive was applied to the forage in plastic bags by hand using a spray bottle, and then the contents of the bag were mixed thoroughly. The second forage fraction was left untreated and served as a control. Forage from each fraction was then ensiled in 3 laboratory silos $(1.7 \mathrm{~L}$ with a fermentation lock on the lid). Immediately after filling the silos, water was added in the fermentation locks to achieve airtight sealing. Six silos were made from each forage, resulting in a cumulative total of 78 silos for the entire project. The silos were stored at room temperature $\left(20-24^{\circ} \mathrm{C}\right)$ for at least $90 \mathrm{~d}$.

\section{Sampling and Analyses}

Two samples of the fresh crop (before additive application) were collected from each forage. The microbiological composition of the fresh crops was described by measuring lactic acid bacteria (LAB) growth and, for the difficult-to-ensile forages, clostridial spores. Clostridial spores and LAB counts were determined using the spread plate methods described by Jonsson (1990) and Pahlow (1990), respectively. Chemical analyses were used to determine the contents of DM, ash, $\mathrm{CP}$, water-soluble carbohydrates (WSC) and nitrite, as well as the buffering capacity (BC) of the harvested crops. The concentration of DM was analyzed in 2 steps. First, fresh samples weighing approximately $150 \mathrm{~g}$ were dried for $18 \mathrm{~h}$ in a ventilated oven at $65^{\circ} \mathrm{C}$ and milled through a $1.0-\mathrm{mm}$ sieve. Final DM concentration was achieved by drying the milled sample at $103^{\circ} \mathrm{C}$ for $5 \mathrm{~h}$. Concentration of ash were determined by combusting at $550^{\circ} \mathrm{C}$ for $3 \mathrm{~h}$ in a muffle furnace. The concentrations of WSC and nitrate were all analyzed using an extract derived from dried silage samples that were diluted with $250 \mathrm{~mL}$ of distilled water, boiled for $10 \mathrm{~min}$, and drained through H-602 filter paper (Whatman GmbH, Dassel, Germany). Concentrations of WSC were determined using enzyme-based acid hydrolysis (Larsson and Bengtsson, 1983), whereas nitrate concentrations were determined according to method ASN 110-01/92 in the FIA-system from FOSS-Tecator (1992b). Concentration of $\mathrm{CP}$ was analyzed using the Kjeldahl technique with $\mathrm{Cu}$ as a catalyst (Bremner and Breitenbeck, 1983), and buffering capacity measurements were made according to the methods of McDonald and Henderson (1962).

The silos were weighed at the time of filling $(\mathrm{d} 0)$ and again at $\mathrm{d} 3,10,30,60$, and at the end of storage to determine weight losses. Weight losses, assumed to be the result of carbon dioxide production, were expressed in grams per kilogram of DM content in the silo at filling.

On the last day of each storage period, the silo contents were emptied into a separate plastic bag, mixed 
thoroughly, and sampled. Microbiological analyses consisted of clostridial-spore and lactate-assimilating yeast counts. Yeast count was determined using the spread plate method. Serial dilutions of silage samples were cultured aerobically at $25^{\circ} \mathrm{C}$ on malt-extract agar, supplemented with penicillin $\mathrm{G}$ (30 $\mathrm{mg} / \mathrm{L})$, and streptomycin sulfate $(30 \mathrm{mg} / \mathrm{L})$. Chemical analyses were used to determine the concentration of $\mathrm{DM}, \mathrm{pH}$, ammonia N (ASN 50-01/92 in FIA-system from FOSS-Tecator, 1992a), concentration fatty acids (lactic acid, acetic acid, and butyric acid), ethanol, and 2,3-butanediol in silages. Concentration of DM was analyzed in the same way as with the fresh forage, except that a $1.4 \%$ unit as a constant correction for silage volatiles was added to the final calculation (Lingvall and Ericson, 1981). Silage $\mathrm{pH}$ was determined using a $\mathrm{pH}$ electrode $(654 \mathrm{pH}$ meter, Metrom AG, Herisau, Switzerland) in the silage extract. Concentrations of fatty acids, ethanol, and 2,3-butanediol were determined from silage juice using HPLC according to Andersson and Hedlund (1983).

Aerobic stability in the silages was determined at the end of the storage period by measuring temperature increases, assuming that temperature increases are caused by respiration among microorganisms and are thereby an indication of the onset of aerobic deterioration in silage. The number of days it took for a silage to increase $2^{\circ} \mathrm{C}$ and then $5^{\circ} \mathrm{C}$ was used to express aerobic stability (Hönig, 1990). Silage temperature was measured in 1,300-mL PVC tubes covered at the bottom with a polyurethane-fiber net. Packing density was decided in relation to DM concentration according to the following equation: filling weight ( $\mathrm{g}$ of $\mathrm{FM})=$ $[-205.57 \times \ln (\% \mathrm{DM})]+1,061)$ based on DLG (2006) recommendations. Tubes were placed in an insulating Styrofoam block and kept at room temperature for 5 to $7 \mathrm{~d}$.

\section{Statistical Analyses}

Crops were divided into 3 groups according to DM content and $\mathrm{FC}(\mathrm{FC}=\mathrm{DM}+(8 \times \mathrm{WSC} / \mathrm{BC})$, where $\mathrm{BC}=$ buffering capacity) by Reuter and Weissbach (1991) as presented in Table 2. The first group included forages that were difficult to ensile (DIFF) with FC $<35$, the second group comprised easy- or intermediateto-ensile forages (EI-LO) with low DM concentrations $(<350 \mathrm{~g} / \mathrm{kg})$ and $\mathrm{FC}>35$, and the third group represented easy- or intermediate-to-ensile forages (EI-HI) with high DM concentrations $(>350 \mathrm{~g} / \mathrm{kg})$ and $\mathrm{FC}>35$. Statistical analyses were performed using the GLM procedure of the SAS computer package (SAS Institute, 1990). The ANOVA in a completely randomized design was used to evaluate the effect of silage additive treatment and crop type (group) on silage quality. The mean

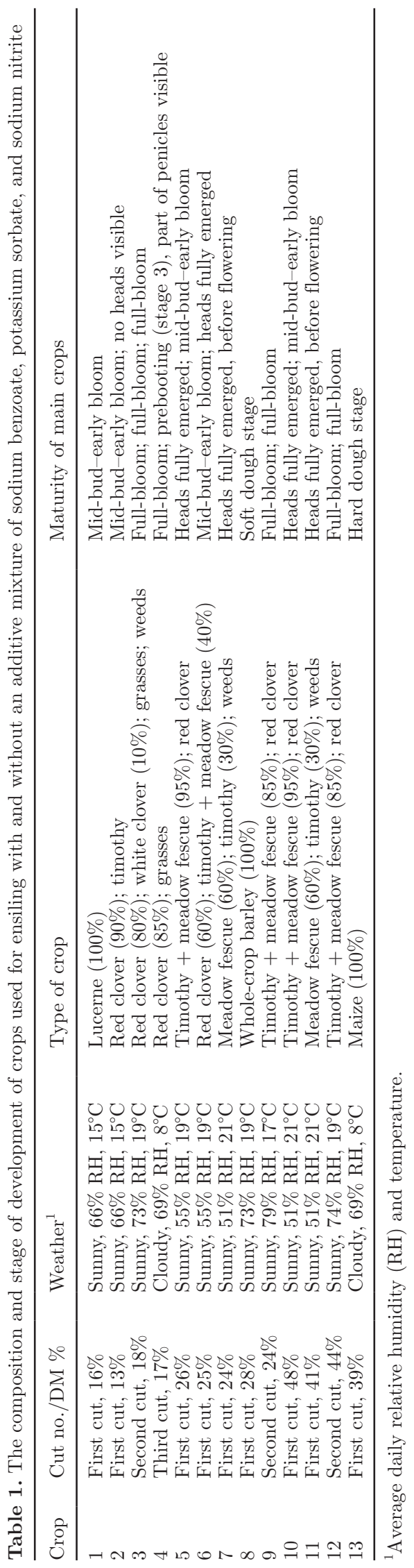


Table 2. The composition of forages before ensiling ( $\mathrm{n}=2$ per crop)

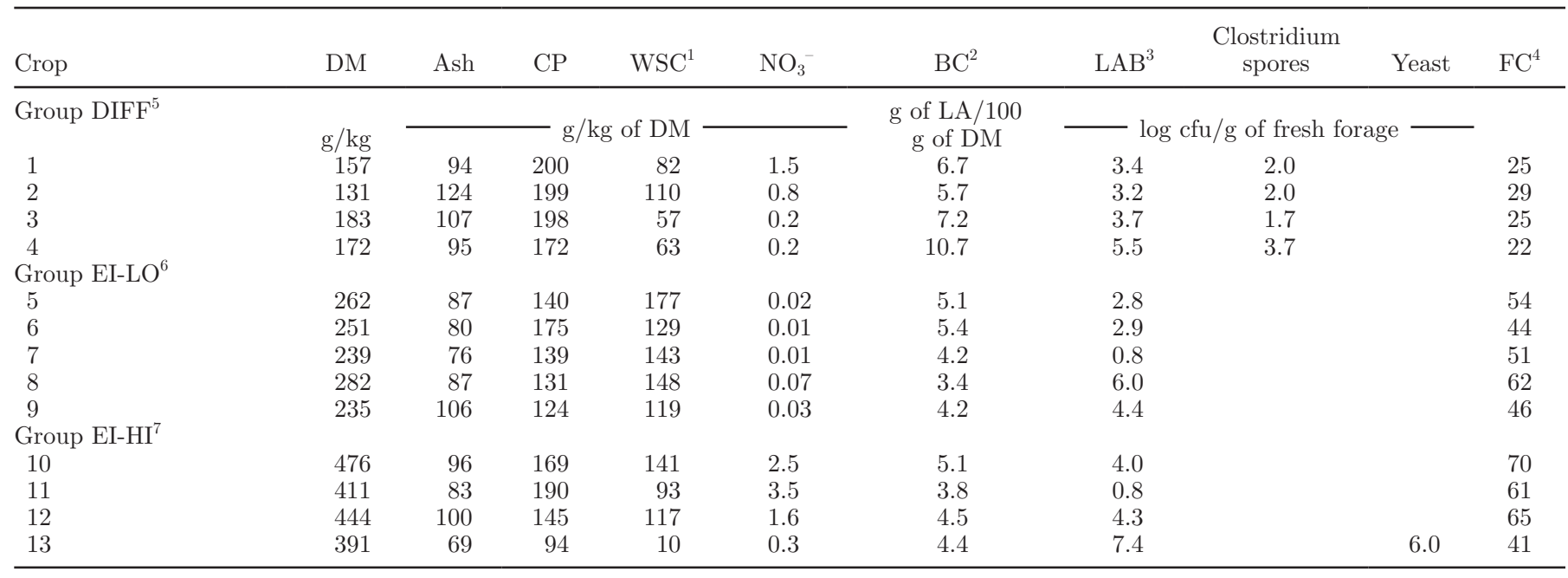

${ }^{1} \mathrm{WSC}=$ water-soluble carbohydrates.

${ }^{2} \mathrm{BC}=$ buffering capacity.

${ }^{3} \mathrm{LAB}=$ lactic acid bacteria.

${ }^{4} \mathrm{FC}=$ fermentation coefficient; $\mathrm{FC}=\mathrm{DM}+(8 \times \mathrm{WSC} / \mathrm{BC})$.

${ }^{5} \mathrm{DIFF}=$ difficult-to-ensile crops.

${ }^{6} \mathrm{EI}-\mathrm{LO}=$ easy- or intermediate-to-ensile crops at DM $<350 \mathrm{~g} / \mathrm{kg}$.

${ }^{7} \mathrm{EI}-\mathrm{HI}=$ easy- or intermediate-to-ensile crops at DM $>350 \mathrm{~g} / \mathrm{kg}$.

of 3 treatment replicates for each crop was considered as the experimental unit. When the calculated values of $F$ were significant, the $t$-test was used to interpret any significant differences among the mean values at a 0.05 probability level.

The statistical model was as follows:

$$
\begin{gathered}
\mathrm{Y}_{\mathrm{ij}}=\mu+\text { treatment }_{\mathrm{i}}+{\text { crop } \operatorname{group}_{\mathrm{j}}} \\
+\left(\text { treatment } \times \text { crop group }_{\mathrm{ij}}+\text { error }_{\mathrm{ijk}},\right.
\end{gathered}
$$

where $\mu=$ overall mean, $\mathrm{i}=$ additive treatment, $\mathrm{j}=$ number of crop groups, and $\mathrm{k}=$ replicate silos.

\section{RESULTS}

The FC values, chemical composition, and microbial activity of the crops before ensiling are presented in Table 2. The concentration of WSC tended to be higher in the EI-LO and EI-HI groups of forages than in the DIFF group, except for crop 13, which had low WSC due to harvest after frost.

The characteristics of treated and untreated silages for each crop group are presented in Table 3. Silages of crops in the DIFF group were characterized by a higher formation of ammonia $\mathrm{N}(P<0.02)$ and acetic acid $(P<0.001)$ than silages from the EI-HI group. On the other hand, the average ethanol concentration was highest $(P<0.02)$ in silages from the EI-LO group of crops. Ethanol formation was lower $(P<0.02)$ in treated silages than in untreated ones in both the DIFF and EI-LO crop groups. The effect of additive treatment was most pronounced in the DIFF group of crops, where additive treated silages were found to have lower $\mathrm{pH}(P<0.04)$, lower ammonia $\mathrm{N}$ concentration $(P<$ $0.002)$, and higher lactic acid concentration $(P<0.01)$ than untreated silages. There also was a tendency for additive treatments to reduce 2,3-butanediol formation in silages $(P=0.09)$ of the DIFF and EI-LO crop groups.

Additive application resulted in a considerable reduction in clostridia spore count $(P<0.03)$ and butyric acid formation $(P<0.01)$ in silages of the DIFF and EI-LO group of crops. Moreover, untreated silages from the EI-LO group contained markedly less butyric acid $(P<0.01)$ than those in the DIFF group. Similarly, lactic acid concentrations were lower $(P<0.03)$ in treated silages from the EI-LO group compared with those from the first group.

The influence of additive treatment in the EI-HI group of crops was a reduced yeast growth in silages $(P$ $<0.03)$ and, simultaneously, an improvement of aerobic stability (Table 4).

Additive treatment was found to reduce weight losses throughout the ensiling period in all crop groups compared with the untreated controls (Figure 1, Table 5); however, only differences in the DIFF and EI-LO groups were highly significant $(P<0.001)$. Furthermore, weight 
Table 3. Chemical and microbiological compositions of silages at the end of storage

\begin{tabular}{|c|c|c|c|c|c|c|c|c|c|c|c|}
\hline Treatment & $\mathrm{DM}$ & $\mathrm{pH}$ & $\mathrm{NH}_{3}-\mathrm{N}$ & $\begin{array}{l}\text { Propionic } \\
\text { acid }\end{array}$ & $\begin{array}{l}\text { Lactic } \\
\text { acid }\end{array}$ & $\begin{array}{l}\text { Acetic } \\
\text { acid }\end{array}$ & $\begin{array}{l}\text { Butyric } \\
\text { acid }\end{array}$ & 2,3-Butandiol & Ethanol & $\begin{array}{l}\text { Lactate } \\
\text { yeasts }\end{array}$ & $\begin{array}{l}\text { Clostridium } \\
\text { spores }\end{array}$ \\
\hline \multirow{2}{*}{$\begin{array}{l}\text { DIFF }^{1} \\
\text { Untreated } \\
\text { Treated }\end{array}$} & \multicolumn{2}{|l|}{$\mathrm{g} / \mathrm{kg}$} & $\begin{array}{l}\mathrm{g} / \mathrm{kg} \text { of } \\
\text { total } \mathrm{N}^{2}\end{array}$ & \multicolumn{4}{|c|}{$-\mathrm{g} / \mathrm{kg}$ of $\mathrm{DM}$} & & & \multicolumn{2}{|c|}{$\begin{array}{l}\text { log cfu/g of } \\
\text { fresh matter }\end{array}$} \\
\hline & 166 & $4.2^{\mathrm{b}}$ & $51.7^{\mathrm{bc}}$ & $1.7^{\mathrm{a}}$ & $122.2^{\mathrm{a}}$ & $21.5^{\mathrm{b}}$ & $0.4^{\mathrm{c}}$ & $1.7^{\mathrm{a}}$ & $3.5^{\mathrm{c}}$ & 1.7 & $1.9^{\mathrm{b}}$ \\
\hline \multicolumn{12}{|l|}{ EI-LO ${ }^{3}$} \\
\hline Untreated & 240 & $4.5^{\mathrm{ab}}$ & $105.8^{\mathrm{b}}$ & $2.5^{\mathrm{a}}$ & $56.7^{\mathrm{bc}}$ & $10.8^{\mathrm{bc}}$ & $20.7^{\mathrm{b}}$ & $14.3^{\mathrm{a}}$ & $21.2^{\mathrm{a}}$ & $2.1^{\mathrm{b}}$ & $4.5^{\mathrm{a}}$ \\
\hline \multicolumn{12}{|l|}{ EI-HI ${ }^{4}$} \\
\hline Treated & 425 & 4.8 & $24.0^{\mathrm{cd}}$ & 1.7 & $26.5^{\mathrm{c}}$ & $6.7^{\mathrm{bc}}$ & 0.4 & $1.6^{\mathrm{a}}$ & $5.1^{\mathrm{bc}}$ & 1.7 & 1.7 \\
\hline SEM & & 0.23 & 23.32 & 1.06 & 13.83 & 4.68 & 7.69 & 5.00 & 2.34 & 0.43 & 0.53 \\
\hline \multicolumn{12}{|l|}{$P$-value } \\
\hline Treatment & & 0.04 & 0.002 & 0.06 & 0.01 & 0.3 & 0.001 & 0.09 & 0.001 & 0.03 & 0.001 \\
\hline Crop group & & 0.2 & 0.02 & 0.1 & 0.003 & 0.001 & 0.01 & 0.4 & 0.02 & 0.06 & 0.02 \\
\hline Treatment $\times$ crop group & & 0.2 & 0.1 & 0.1 & 0.03 & 0.1 & 0.01 & 0.5 & 0.08 & 0.06 & 0.03 \\
\hline
\end{tabular}

${ }^{\mathrm{a}-\mathrm{d}}$ Values within columns with different superscripts are significantly different at $P<0.05(\mathrm{n}=26)$.

${ }^{1} \mathrm{DIFF}=$ difficult-to-ensile crops.

${ }^{2}$ The value is corrected for $\mathrm{N}$ added with the additive in form of $\mathrm{NaNO}_{2}$.

${ }^{3} \mathrm{EI}-\mathrm{LO}=$ easy- or intermediate-to-ensile crops at DM $<350 \mathrm{~g} / \mathrm{kg}$.

${ }^{4} \mathrm{EI}-\mathrm{HI}=$ easy- or intermediate-to-ensile crops at DM $>350 \mathrm{~g} / \mathrm{kg}$.

losses in silages from the DIFF and EI-LO groups were higher $(P<0.001)$ than in the EI-HI group.

\section{DISCUSSION}

The type and composition of forage used in each group of crops clearly affected the characteristics of fermented silages. The majority of forages that were difficult to ensile (DIFF group) were legumes harvested at low concentrations of DM. Legumes are difficult to preserve as they tend to have relatively high buffering capacity and low concentrations of WSC. Silages made from legumes with low DM contents have very low FC values and are particularly vulnerable to growth of undesirable microorganisms, such as Clostridia spp., during fermentation. Typical characteristics of clostridial silages are elevated concentrations of butyric acid and ammonia N, reduced concentrations of lactic acid, and greater silage $\mathrm{pH}$ (Pahlow et al., 2003). These characteristics are often accompanied with increased silage DM

Table 4. Storage stability of silages treated or not with an additive mixture of sodium benzoate, potassium sorbate, and sodium nitrite expressed in temperature increase

\begin{tabular}{|c|c|c|c|c|}
\hline Treatment & $\begin{array}{c}\text { Days until } \\
\text { temperature-aerated } \\
\text { silages increased } \\
\text { by } 2^{\circ} \mathrm{C}\end{array}$ & $\begin{array}{c}\text { Days until } \\
\text { temperature-aerated } \\
\text { silages increased } \\
\text { by } 5^{\circ} \mathrm{C}\end{array}$ & $\begin{array}{l}\text { Maximum } \\
\text { temperature, } \\
{ }^{\circ} \mathrm{C}\end{array}$ & $\begin{array}{l}\text { Maximum } \\
\text { temperature } \\
\text { increase, }{ }^{\circ} \mathrm{C}\end{array}$ \\
\hline \multicolumn{5}{|l|}{ DIFF $^{1}$} \\
\hline Untreated & 6.1 & 6.1 & 18.3 & 1.1 \\
\hline Treated & 6.1 & 6.1 & 18.4 & 1.1 \\
\hline \multicolumn{5}{|l|}{ EI-LO $^{2}$} \\
\hline Untreated & $5.4^{\mathrm{a}}$ & $5.6^{\mathrm{a}}$ & 20.5 & 2.5 \\
\hline Treated & $6.0^{\mathrm{a}}$ & $6.1^{\mathrm{a}}$ & 18.9 & 0.9 \\
\hline \multicolumn{5}{|l|}{ EI-HI ${ }^{3}$} \\
\hline Untreated & $3.2^{\mathrm{b}}$ & $3.5^{\mathrm{b}}$ & 23.9 & 5.9 \\
\hline Treated & $6.1^{\mathrm{a}}$ & $6.1^{\mathrm{a}}$ & 18.7 & 0.9 \\
\hline SEM & 0.67 & 0.64 & & \\
\hline \multicolumn{5}{|l|}{$P$-value } \\
\hline Treatment & 0.04 & 0.05 & & \\
\hline Crop group & 0.1 & 0.1 & & \\
\hline Treatment $\times$ crop group & 0.1 & 0.1 & & \\
\hline
\end{tabular}



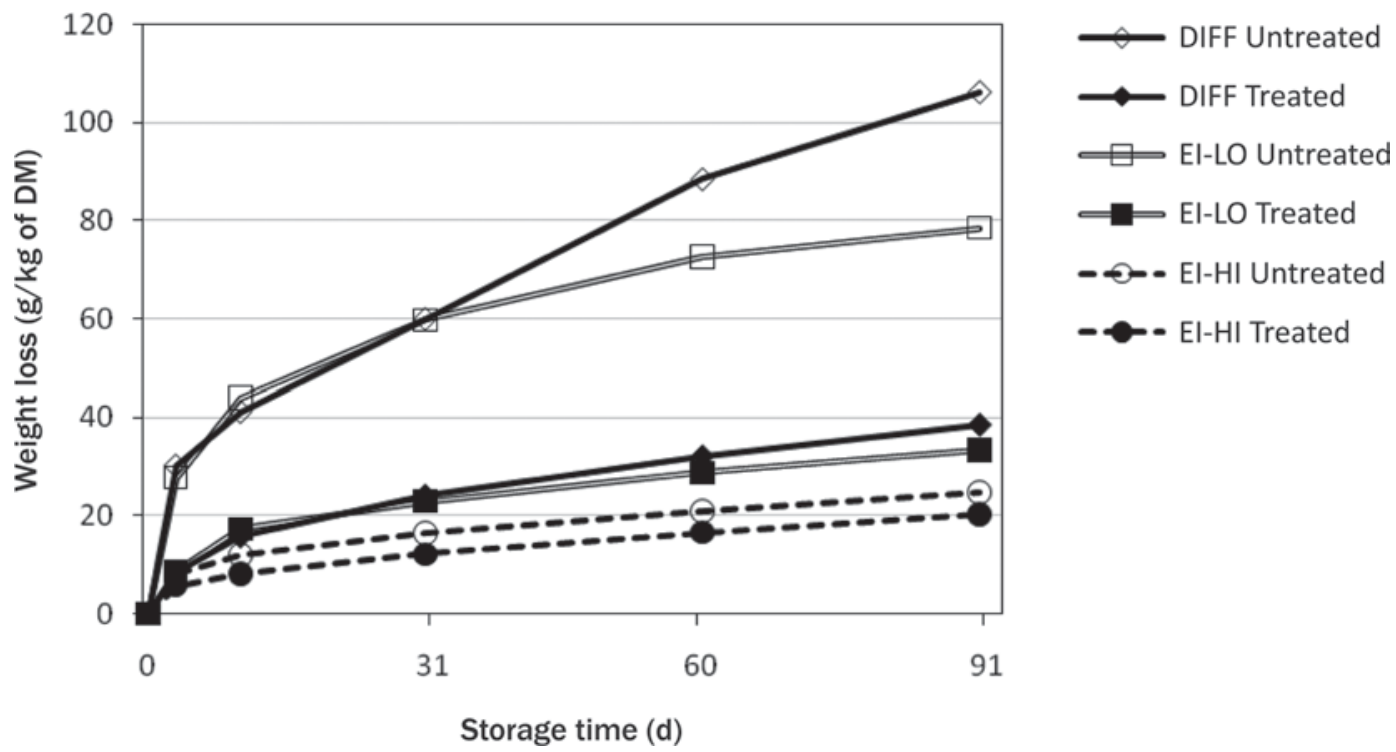

Figure 1. Weight losses during storage of silages treated or not with an additive mixture of sodium benzoate, potassium sorbate, and sodium nitrite $(\mathrm{n}=26)$. DIFF $=$ difficult-to-ensile crops; EI-LO = easy- or intermediate-to-ensile crops at DM $<350 \mathrm{~g} / \mathrm{kg}$; EI-HI $=$ easy- or intermediate-to-ensile crops at DM $>350 \mathrm{~g} / \mathrm{kg}$.

losses and high clostridial spore counts (Pahlow et al., 2003). It is therefore not surprising that the untreated control silages of difficult-to-ensile crops all displayed the typical characteristics of clostridial fermentations in this experiment. The most probable explanation for this development was that the WSC concentrations in wet crops were too low to maintain lactic acid production by LAB that would otherwise decrease silage $\mathrm{pH}$ enough to permanently inhibit clostridia. Consequently,

Table 5. Weight losses of ensiled crops at opening after $90 \mathrm{~d}$ of ensiling

\begin{tabular}{lc}
\hline Treatment & $\begin{array}{c}\text { Weight loss, } \\
\text { g/kg of DM }\end{array}$ \\
\hline DIFF $^{1}$ & \\
Untreated & $103.6^{\mathrm{a}}$ \\
Treated & $38.6^{\mathrm{b}}$ \\
EI-LO $^{2}$ & \\
Untreated & $78.5^{\mathrm{a}}$ \\
Treated & $33.4^{\mathrm{b}}$ \\
EI-HI & \\
Untreated & $24.9^{\mathrm{b}}$ \\
Treated & $20.3^{\mathrm{b}}$ \\
SEM & 1.03 \\
P-value & \\
Treatment & 0.001 \\
Crop group & 0.001 \\
Treatment $\times$ crop group & 0.03 \\
\hline
\end{tabular}

${ }^{\mathrm{a}, \mathrm{b}}$ Values within columns with different superscripts are significantly different at $P<0.05(\mathrm{n}=26)$.

${ }^{1} \mathrm{DIFF}=$ difficult-to-ensile crops.

${ }^{2} \mathrm{EI}-\mathrm{LO}=$ easy- or intermediate-to-ensile crops at DM $<350 \mathrm{~g} / \mathrm{kg}$.

${ }^{3} \mathrm{EI}-\mathrm{HI}=$ easy- or intermediate-to-ensile crops at DM $>350 \mathrm{~g} / \mathrm{kg}$. clostridia probably fermented the lactic acid to butyric acid and eventually overwhelmed the LAB. Conversely, silages treated with the additive mixture showed a fermentation process dominated by LAB as evidenced by their low pH and a high lactic acid concentration.

The next set of crops (EI-LO group) was determined to be easily or intermediately ensilable with low DM concentration, which did not exceeding $300 \mathrm{~g} / \mathrm{kg}$. Accordingly, these crops consisted mainly of grasses, which generally possess high WSC concentrations and a low buffering capacity, giving them high FC. However, even such a crop composition was insufficient to eliminate clostridial growth in 4 out of the 5 untreated silages. The sufficient concentration of WSC in the crops probably prevented clostridia domination, but indicators of clostridia, such as high $\mathrm{pH}$, the presence of butyric acid, and increased ammonia $\mathrm{N}$ formation (Pahlow et al., 2003), as well as clostridia spores were nonetheless detected. Additive-treated silages, unlike the untreated ones, were well fermented without any sign of clostridial activity. The decreased activity among undesirable microorganisms (clostridia and yeasts) during fermentation can explain the significantly smaller silage losses among the silages treated with the additive mixture (Pahlow et al., 2003).

The present experiment shows that a high risk of clostridia proliferation exists in silages without additives when concentrations of DM are $<300 \mathrm{~g} / \mathrm{kg}$. Results from this study also confirm earlier finding that wilting crops to $300 \mathrm{~g} / \mathrm{kg}$ of FM is insufficient to inhibit clostridial growth in silages and that for complete 
inhibition, DM concentration needs to be $>400 \mathrm{~g} / \mathrm{kg}$ (Jonsson et al., 1990). Such inhibition was achieved in the next set of crops with easily or intermediately ensilable forages with a relatively high DM concentration (EI-HI group). These crops were composed mainly of grasses characterized by high WSC concentrations and low buffering capacity, resulting in high FC. Silages made from these crops were clostridia free, exhibiting only minimal concentrations of butyric acid. Because of the high DM content, LAB activity in these silages also was restricted, resulting in a low production of fermentation acids and consequently higher $\mathrm{pH}$ (McDonald et al., 1991). A common problem with highly wilted silages is that they often exhibit poor aerobic stability. Poor aerobic stability of silages is associated with the growth of yeasts (Woolford, 1990), particularly lactate-assimilating yeasts (Jonsson and Pahlow, 1984), which is accompanied by an increase in temperature. This relationship was well demonstrated in our study, where untreated control silages contained more yeast and also were found to have poorer aerobic stability. The problem with poor aerobic stability does not occur in silages dominated by clostridial fermentation due to the high concentrations of butyric acid, which inhibits yeast growth (Weissbach and Haacker, 1988). Therefore, it is predominately well-fermented silages that are susceptible to aerobic deterioration. In this regard, results from the present study showed that the additive mixture considerably restricted yeast growth in all silages and caused those silages to be aerobically stable throughout the experiment.

The present investigation confirms earlier findings by Knicky and Spörndly (2009) that a mixture of sodium benzoate, potassium sorbate, and sodium nitrite efficiently improves silage quality for crops with both high and low DM content. This broad ensiling efficiency was achieved despite considerably lower nitrite concentration and without the presence of hexamine, which can be found in similarly efficient additive mixtures, which were examined previously by Lättemäe and Lingvall (1996), Lingvall and Lättemäe (1999), and Knicky and Lingvall (2004). Collectively, the increased concentration of sodium benzoate with the presence of potassium sorbate successfully substituted for the antibacterial properties of hexamine that degrades during ensiling to formaldehyde, which is a prohibited additive in many countries.

\section{CONCLUSIONS}

The application of a mixture of sodium benzoate, potassium sorbate, and sodium nitrite considerably decreases clostridial growth in crops with DM contents $<300 \mathrm{~g} / \mathrm{kg}$, as demonstrated by reduced ammonia $\mathrm{N}$ and butyric acid formation. In crops with DM contents $>350 \mathrm{~g} / \mathrm{kg}$, the same additive mixture efficiently eliminated yeast activity in silages. The application of the additive mixture guarantees prolonged storage stability in a broad range of silages.

\section{ACKNOWLEDGMENTS}

The authors thank AB Hanson and Möhring (Halmstad, Sweden) for funding parts of the project.

\section{REFERENCES}

Andersson, R., and B. Hedlund. 1983. HPLC analysis of organic acids in lactic acid fermented vegetables. Z. Lebensm. Unters. Forsch. 176:440-443.

Bremner, J. M., and G. A. Breitenbeck. 1983. A simple method for determining ammonium in semi-micro Kjeldahl analysis of soil and plant materials using block digester. Commun. Soil Sci. Plant Anal. 14:905-913.

DLG. 2006. DLG-Richtlinien für die Prüfung von Siliermitteln auf DLG-Gütezeichen-Fähigkeit. [DLG guidelines for the test of silage additives for approval of DLG quality labels.] DLG Commission for Silage Additives, Frankfurt a.M., Germany.

FOSS-Tecator. 1992a. Ammonia. Application Note ASN 50-01/92. Tecator, Höganäs, Sweden.

FOSS-Tecator. 1992b. Nitrate (Cadmium Reduction Method). Application Note ASN 110-01/92. Tecator, Höganäs, Sweden.

Gross, F., and T. H. Beck. 1972. Vergleichende Untersuchungen über die Wirkung von Silierhilfsmitteln. [Comparative investigations on the effect of silage additives.] Z. Wirtschaftseigene Futter 18:161-177.

Honig, H. 1990. The evaluation of aerobic stability. Pages 76-82 in Proc. EUROBAC Conf., Uppsala, Sweden. P. Lingvall and S. Lindgren, ed. Grass and Forage Reports 3. Swedish Univ. of Agric. Sciences, Uppsala.

Jonsson, A. 1990. Enumeration and confirmation of C. tyrobutyricum in silages using neutral red, D-cycloserine, and lactate dehydrogenase activity. J. Dairy Sci. 73:719-725.

Jonsson, A., H. Lindberg, S. Sundås, and P. Lingvall. 1990. Effect of additives on the quality of big-bale silage. Anim. Feed Sci. Technol. 31:139-155.

Jonsson, A., and G. Pahlow. 1984. Systematic classification and biochemical characterisation of yeasts growing in grass silage inoculated with Lactobacillus cultures. Anim. Res. Develop. 20:7-22.

Kleinschmit, D. H., R. J. Schmidt, and L. Kung, Jr.. 2005. The effects of various antifungal additives on the fermentation and aerobic stability of corn silage. J. Dairy Sci. 88:2130-2139.

Knicky, M., and P. Lingvall. 2004. Ensiling of high wilted grass-clover mixture by use of different additives to improve the hygienic quality. Acta Agric. Scand. Anim. Sci. 54:197-205.

Knicky, M., and R. Spörndly. 2009. Sodium benzoate, potassium sorbate and sodium nitrite as silage additives. J. Sci. Food Agric. 89:2659-2667.

Kwella, M., K. Haaker, and B. Reuter. 1993. About investigations on the efficiency of silage additives. Pages 99-100 in Proc. 10th Int. Conf. on Silage Research. Dublin City Univ., Ireland.

Larsson, K., and S. Bengtsson. 1983. Bestämning av lätt tillgängliga kolhydrater i växtmaterial. [Determination of non structural carbohydrates in plant material] Method description No. 22. National Laboratory for Agric. Chemistry, Uppsala, Sweden.

Lättemäe, P., and P. Lingvall. 1996. Effect of hexamine and sodium nitrite in combination with sodium benzoate and sodium propionate on fermentation and storage stability of wilted and long cut grass silage. Swedish J. Agric. Res. 26:135-146.

Lingvall, P., and B. Ericson. 1981. Dry matter determination of silage. Mimeo. Swedish University of Agricultural Sciences, Dept. of Animal Nutrition and Management, Uppsala, Sweden. 
Lingvall, P., and P. Lättemäe. 1999. Influence of hexamine and sodium nitrite in combination with sodium benzoate and sodium propionate of fermentation and hygienic quality of wilted and long cut grass silage. J. Sci. Food Agric. 79:257-264.

McDonald, P., and A. R. Henderson. 1962. Buffering capacity of herbage samples as a factor in ensilage. J. Sci. Food Agric. 13:395400.

McDonald, P., A. R. Henderson, and S. J. E. Heron. 1991. Page 111 in The Biochemistry of Silage. Chalcombe Publications, Marlow, Bucks, UK

Pahlow, G. 1990. Untersuchung des epiphytischen Besatzes von Siliergut mit Milchsäurebakterien. [Determination of epiphytic LAB in ensiled forage.] Unpublished paper, Bundesforschungsanstalt für Landwirtschaft (FAL), Institut für Grünland- und Futterpflanzenforschung, Braunschweig, Germany.

Pahlow, G., R. E. Muck, F. Driehuis, and S. J. W. H. Oude Elferink. 2003. Microbiology of ensiling. Page 50 in Silage Science and Technology. D. R. Buxton, R. E. Muck, and J. H. Harrison, ed. Madison, WI.

Reuter, B., and F. Weissbach. 1991. Results of testing chemical preservatives. Pages 338-341 in Proc. of a Conf. on Forage Conservation towards 2000. G. Pahlow and H. Honig, ed. Institute of Grassland and Forage Research, Federal Research Center of Agriculture (FAL), Braunschweig, Germany.
SAS Institute. 1990. SAS/STAT User's Guide. Version 6. 4th ed. SAS Institute Inc., Cary, NC.

Spoelstra, S. F. 1983. Inhibition of clostridial growth by nitrate during the early phase of silage fermentation. J. Sci. Food Agric. $34: 145-152$

Weissbach, F. 1996. New developments in crop conservation. Pages 11-25 in Proc. of the 11th Int. Silage Conference. D. I. H. Jones, R. Dewhurst, R. Merry, and P. M. Haigh. ed. IGER Publ. Section, Aberystwyth, UK.

Weissbach, F., and K. Haacker. 1988. On the causes of butyric acid fermentation in silages from whole crop cereals. Z. Wirtschaftseigene Futter 3:88-99

Weissbach, F., L. Schmid, and E. Hein. 1974. Method of anticipation of the run of fermentation in silage making based on chemical composition of green fodder. Pages 663-673 in Proc 12th Int. Grassland Congr., Moscow, Russia.

Woolford, M. K. 1975. Microbiological screening of food preservatives. Cold sterilants and specific antimicrobial agents as potential silage additives. J. Sci. Food Agric. 26:226-237.

Woolford, M. K. 1978. The aerobic deterioration of silage. ARC Res. Rev. 4:8-12. (Agric. Res. Counc., London, UK.).

Woolford, M. K. 1990. The detrimental effects of air on silage. J. Appl. Bacteriol. 68:101-116. 